\section{Effects of Fire on an Ashe Juniper Community}

\section{ROBERT L. WINK AND HENRY A. WRIGHT}

Highlight: In an ashe juniper (Juniperus ashei) community a minimum of 1,000 $\mathrm{kg} / \mathrm{ha}$ of fine fuel was needed to carry a fire to kill juniper seedlings and burn piles of dozed juniper. Grasses recovered quickly and soil erosion was minimal when burning was done during a wet winter and spring. During a dry winter and spring, however, burning increased drouth stress on plants, reduced herbaceous yields, and exposed soil to wind and water erosion for a long period of time when soil moisture was low.

After nonsprouting juniper species are dozed or chained, unwanted juniper seedlings abound and the piles of dead juniper suppress growth of herbaceous plants and are an obstacle to livestock. Fire can be used as an effective tool to remove dead juniper and to kill young juniper trees, but there is no information on the amount of fine fuel (less than $0.3 \mathrm{~cm}$ in diameter) necessary for effective broadcast burning. Also, the effect of fire on herbaceous plants has not been documented for ashe juniper (Juniperus ashei) communities in central Texas. This study was designed to determine the minimum amount of fine fuel necessary to effectively broadcast burn these communities and to determine the effects of fire on the dominant grass species.

\section{Nature of Juniper and Juniper Invasion}

Junipers usually occupy rocky slopes, such as escarpments, ridges, or rimrocks (Wells, 1970). During the last 50 years, however, juniper has become more prevalent on grasslands (Johnsen, 1962). The most commonly accepted causes for the spread of junipers into grasslands are (1) lack of fire, which kills many small trees and some larger ones; (2) overgrazing, which reduces competition between grasses and seedling juniper; (3) a shift in climate favoring juniper; and (4) increased spread of seed by livestock (Johnsen, 1962).

Juniper invades grassland slowly if a good grass cover exists (Johnsen, 1962). However, if juniper becomes established,

The authors are research assistant and associate professor of range management, Texas Tech University, Lubbock. The senior author's present address is 1105 Ninth Street, Canyon, Texas 79015 .

The study is College of Agricultural Sciences Contribution number T-9-1 12, Texas Tech University, Lubbock.

Manuscript received October 6, 1972. grass production generally decreases. Emerson (1932) found that juniper roots compete directly with grass and forbs for moisture and nutrients.

Jameson (1961) showed that water extracts from juniper foliage reduced growth of wheat radicles $79 \%$ to $85 \%$. Similar effects on the growth of blue grama (Bouteloua gracilis) radicles have been demonstrated (U. S. Forest Service, 1963). Lavin et al. (1968) found that juniper extracts decreased the germination of some range grasses.

\section{Effect of Fire on Juniper}

Fire is the worst natural enemy of eastern redcedar (Arend, 1950), a nonsprouting species similar to ashe juniper. The species cannot maintain itself in areas that burn frequently, the bark being so thin that heat from one surface fire usually kills all trees. Fire has similar effects on other non-sprouting juniper species.

Prescribed burning has given successful results in controlling ashe juniper in Oklahoma (Dalrymple, 1969). With 500 to $1,000 \mathrm{lb} /$ acre (560 to 1,120 $\mathrm{kg} / \mathrm{ha}$ ) of herbaceous fuel, he obtained a $100 \%$ mortality of trees less than $2 \mathrm{ft}(60$ $\mathrm{cm})$ tall, $77 \%$ mortality of trees 2 to $6 \mathrm{ft}$ $(60$ to $180 \mathrm{~cm})$ tall, and $27 \%$ mortality of trees over $6 \mathrm{ft}$ tall $(180 \mathrm{~cm})$, for an average mortality of $68 \%$.

Grass fires readily kill one-seeded juniper up to $3 \mathrm{ft}(90 \mathrm{~cm})$ in height; mortality decreases as tree size increases (Arnold et al., 1964). Dwyer and Pieper (1967) reported that $70 \%$ of the juniper trees exposed to high temperatures of a summer wildfire, eventually died by the following year.

\section{Effect of Fire on Grass}

The response of grass to prescribed burning can be favorable or unfavorable, depending on moisture conditions at time of burning. Aro (1971) reported that recovery of grasses on burned sites was excellent following the burning of pinyon-juniper woodland in the Southwest. Burned areas produced $300 \%$ more herbage than control areas on all sites. By contrast, Dwyer and Pieper (1967) found that blue grama yields decreased the first year after a wildfire in the pinyon-juniper type in New Mexico but had recovered by the second year.

In the mixed prairie, little bluestem (Schizachyrium scoparium) yields gener-

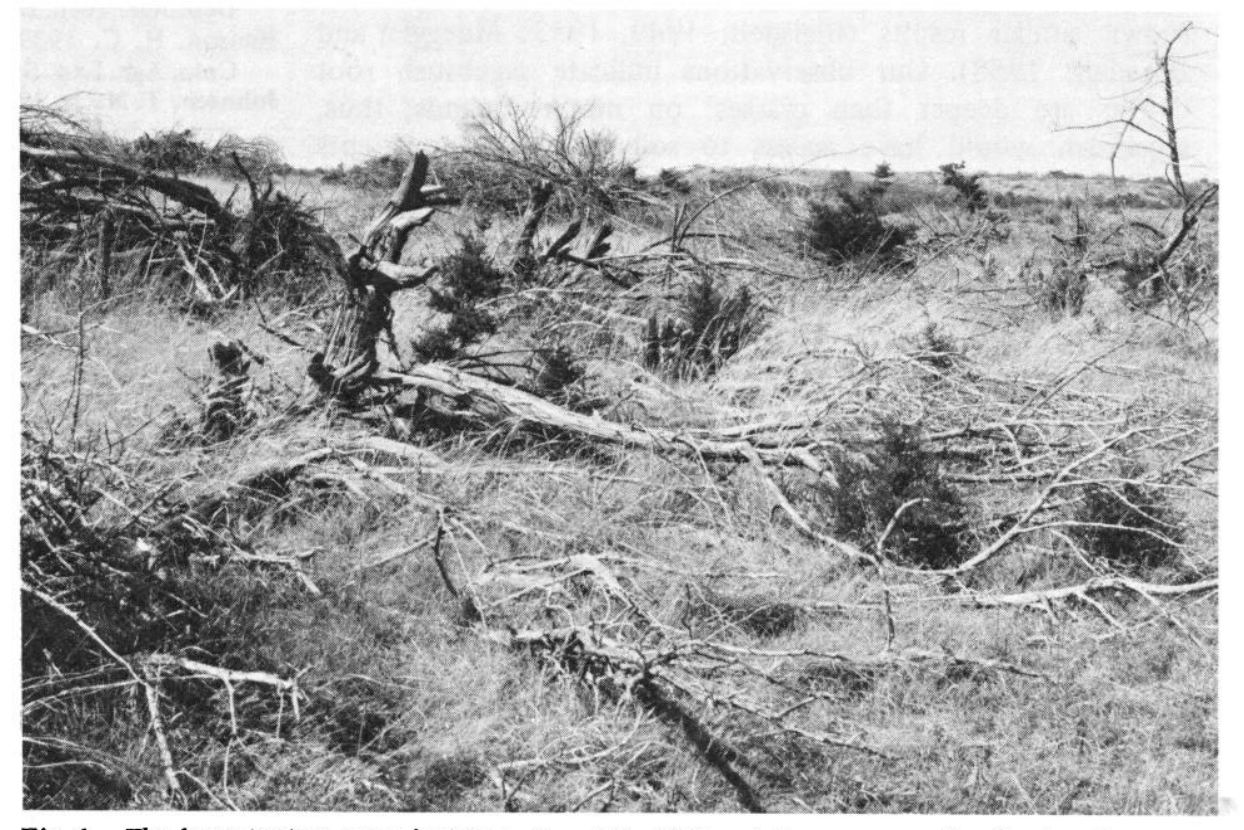

Fig. 1. The large juniper trees had been dozed in 1965 and those too small to be dozed remained alive to renew the original problem at a later date. 
ally increase following prescribed burning (Aldous, 1934), whereas sideoats grama (Bouteloua curtipendula) is not affected (Dix and Butler, 1954). Yield of little bluestem has decreased on some burns because of the season or low soil moisture at the time of the burns (McMurphy and Anderson, 1965). Box et al. (1967) found that meadow dropseed (Sporobolusasper var. Hookeri) increased following burning. Cool season grasses are usually damaged by spring burns (Old, 1969).

\section{Methods and Procedures}

This study was conducted on 1,053 ha of the Beckham Ranch in Callahan County, $24 \mathrm{~km}$ southeast of Baird, Texas. One pasture of 405 ha was burned in March, 1970; two pastures making up 648 ha were burned in March, 1971. Average annual precipitation is 60 to $70 \mathrm{~cm}$. Topography is level to undulating with some slopes greater than $20 \%$. Elevation is 365 to $425 \mathrm{~m}$ above sea level. The average minimum January temperature is $-5^{\circ} \mathrm{C}$ and the average maximum July temperature is $35^{\circ} \mathrm{C}$. The average growing season is 232 days.

Sandy loam and how stony hill range sites are found in the study area. The sandy loam site has deep soils with fine sandy loam surfaces 15 to $36 \mathrm{~cm}$ thick and sandy clays and sandy loam subsoils. The soils are slowly to moderately permeable. They store moderate amounts of available moisture and are fertile enough to support good grass production. The low stony hill site consists of very shallow, moderately permeable, calcareous, stony clay soils. Depth ranges from 15 to $31 \mathrm{~cm}$ with limestone rocks and boulders present on the surface and in the profile in varying amounts. The underlying limestone bedrock is cracked and fissured, forming deep pockets of fine earth capable of supporting deep-rooted grasses and trees. The large amount of rock in the soil improves plant-water relations and makes small rains effective.

Vegetation consists of mixed prairie grasses interspersed with ashe juniper and several species of oak (Quercus spp.). Little bluestem and sideoats grama are the dominant decreasers. Buffalograss (Buchloe dactyloides), vine-mesquite (Panicum obtusum), Texas wintergrass (Stipa leucotricha), tall grama (Bouteloua pectinata), and meadow dropseed are important increasers. All large juniper trees were dozed in 1965, but many small juniper trees were not dozed (Fig. 1).

Two areas, one to be burned and a control, were selected on similar sites in each of two pastures. Yields of total herbage and of five major grass speciesvine-mesquite, little bluestem, tall grama, sideoats grama, and meadow dropseedwere taken in July, 1970 and 1971, on to oven-dry weight. Vegetative cover on burned piles and burned areas without piles were compared by estimating the cover on 100 random $0.22-\mathrm{m}^{2}$ plots in each of the areas.

In the 1971 burn fourteen 0.4 to 0.8 ha plots with uniformly fine fuels varying from 768 to $3,568 \mathrm{~kg} /$ ha were randomly selected to test the effectiveness of fire to burn piles of juniper and to kill young

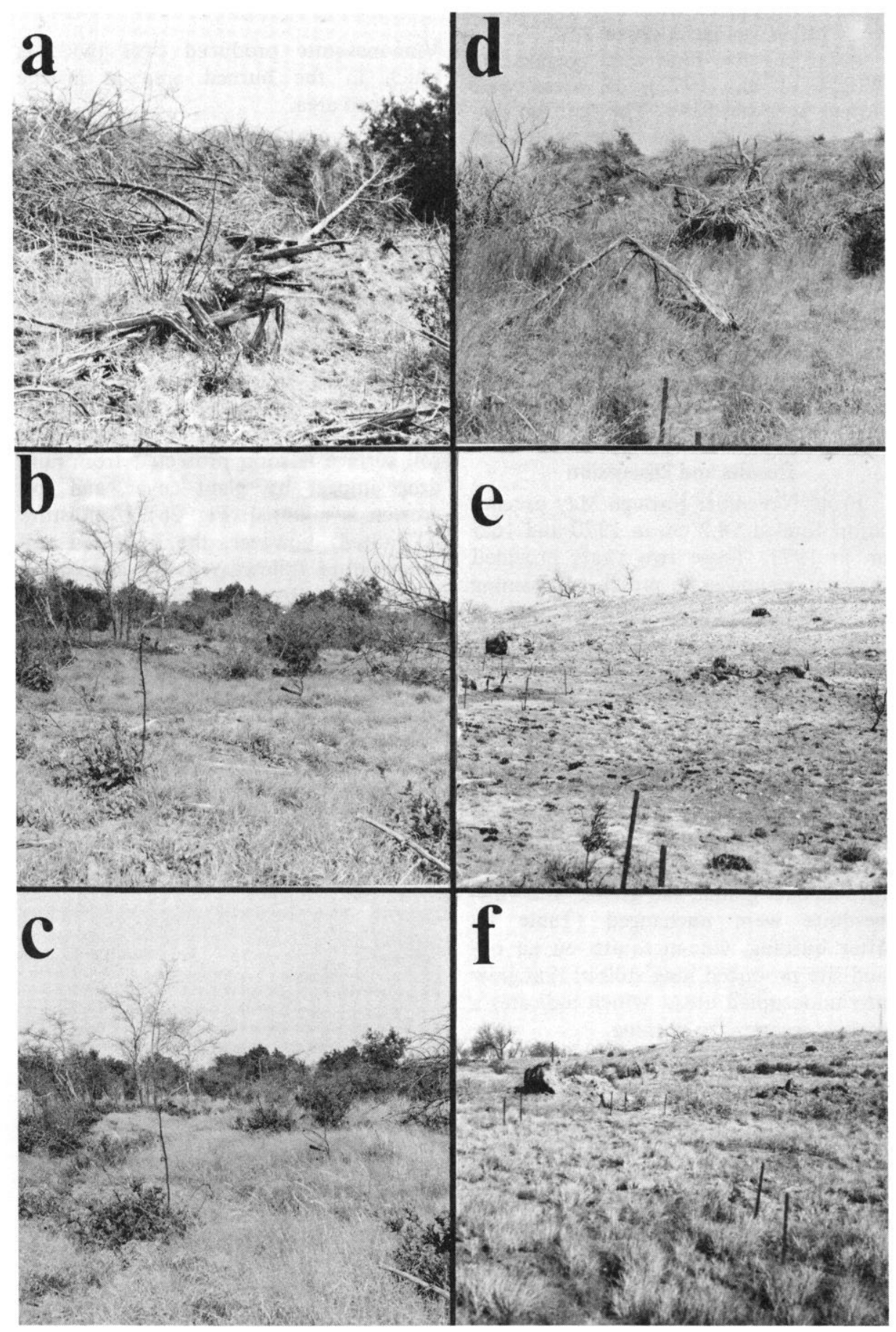

Fig. 2. (a) Before burning during a wet spring in an ashe juniper community, March 25, 1970; (b) good recovery of grasses 6 weeks after the burn on May 15, 1970; (c) complete recovery by July 15, 1970; (d) before burning during a dry spring in an ashe juniper community, March 27, 1971; (e) poor recovery 8 weeks after the burn; (f) still poor recovery on July 16, 1971. Plant growth is comparable to 6-weeks growth during a wet spring (b). 
juniper trees. Twenty-five piles and/or 25 living trees were marked in each site to measure pile consumption and tree mortality.

The amount of fine fuel on each plot was determined by clipping twenty 0.22 $\mathrm{m}^{2}$ frames on each site. The herbaceous vegetation was clipped to the mineral soil surface, dried, and weighed. The estimated amount of heavy fuel (piles of juniper) varied from 44,800 to 67,200 $\mathrm{kg} / \mathrm{ha}$ and occupied from 0 to $85 \%$ of the area with an average cover of $22 \%$.

After the fire lines were constructed (Wright et al., 1972), all areas were burned with headfires. The ignition pattern was a combination of perimeter and strip headfiring. In each pasture, the leeward sides were backfired before the headfires were ignited. The air temperature was 24 to $30^{\circ} \mathrm{C}$, humidity 25 to $35 \%$, and wind speed 16 to $25 \mathrm{~km} / \mathrm{hr}$.

Group comparisons ( $t$-test) were used to determine differences in production of the five major grasses in the burned and unburned areas. Chi-square analyses were used to test for differences in pile consumption and tree mortality on the different fuel sites.

\section{Results and Discussion}

From November through May precipitation totaled $58.2 \mathrm{~cm}$ in 1970 and 16.5 $\mathrm{cm}$ in 1971. These two years provided different responses to prescribed burning and provided good examples of when to burn and when not to burn.

\section{Effect of Fire on Herbage}

Herbaceous yield of the burned area was $41 \%$ more $(P<0.05)$ than the control in $1970(1853$ vs $1312 \mathrm{~kg} / \mathrm{ha})$ and $13 \%$ less $(P<0.05)$ than the control in 1971 (900 vs. $1029 \mathrm{~kg} / \mathrm{ha}$ ). During the wet spring in 1970, burning increased yields of little bluestem and meadow dropseed, but sideoats grama, tall grama, and vinemesquite were unchanged (Table 1). After burning, vine-mesquite on an upland site produced long stolons that grew into unoccupied areas, which indicates a positive response to burning.

Burning during the dry spring in 1971 decreased little bluestem, sideoats grama, and tall grama yields by 50\%. These grasses were on uplands, and the removal of litter by the fire and the remaining black ashes following burning resulted in a hotter and drier environment than in the unburned control. Vine-mesquite and meadow dropseed increased in production in the burned area. These two grasses were on a lowland site and received runoff water from occasional intense storms, which allowed these grasses to take advantage of the higher soil temperatures and litter removal after burning.

Table 1. Production of five grass species (dry weight) following planned spring burns on the Beckham Ranch in 1970 and 1971 (kg/ha).

\begin{tabular}{|c|c|c|c|c|c|c|}
\hline \multirow[b]{2}{*}{ Species } & \multicolumn{3}{|c|}{1970 (Wet year) } & \multicolumn{3}{|c|}{1971 (Dry year) } \\
\hline & Burned & Unburned & Difference & Burned & Unburned & Difference \\
\hline Little bluestem & 4405 & 2429 & $+81 \% *$ & 2289 & 3946 & $-42 \% *$ \\
\hline Tall grama & 2031 & 1447 & $+40 \%$ & 977 & 2460 & $-60 \% *$ \\
\hline Sideoats grama & 1060 & 1208 & $-12 \%$ & 408 & 829 & $-51 \% *$ \\
\hline Vine-mesquite & 4458 & 3434 & $+30 \%$ & 7777 & 3669 & $+112 \% *$ \\
\hline Meadow dropseed & 5631 & 3670 & $+53 \% *$ & 3714 & 3006 & $+24 \% *$ \\
\hline
\end{tabular}

* Significant at the 0.05 level of probability.

Vine-mesquite produced over twice as much in the burned area as in the unburned area.

During a wet year, prescribed burning generally accelerates plant growth (Fig. $2 \mathrm{a}$ to $\mathrm{c}$ ) because it improves soil fertility and raises the soil temperature 2 to $18^{\circ} \mathrm{F}$ (1.2 to $10^{\circ} \mathrm{C}$ ) (Kucera and Ehrenreich, 1962). Raising the soil temperature, providing moisture is not limiting, probably enables soil micro-organisms to begin converting nitrogen to a nitrate form sooner, and thus plants grow rapidly (Fowels and Stephenson, 1934; Burns, 1952). With a rapid rate of recovery, the soil surface is soon protected from raindrop impact by plant cover, and soil erosion is minimal (Fig. 2b). If moisture is limited, however, the increased soil temperature following a fire appears to increase the drouth stress on plants (Fig. $2 \mathrm{~d}$ to $\mathrm{f}$ ) and more of them are apt to die or be severely harmed by fire. Also, since there is very little plant grow th to protect the soil from rain for 2 to 3 months after the fire (Fig. 2e), soil erosion can be significant when rain finally comes. During these dry years, litter serves a very important function as an insulator to minimize the extreme effects of drouth.

When rains finally come 4 to 7 months

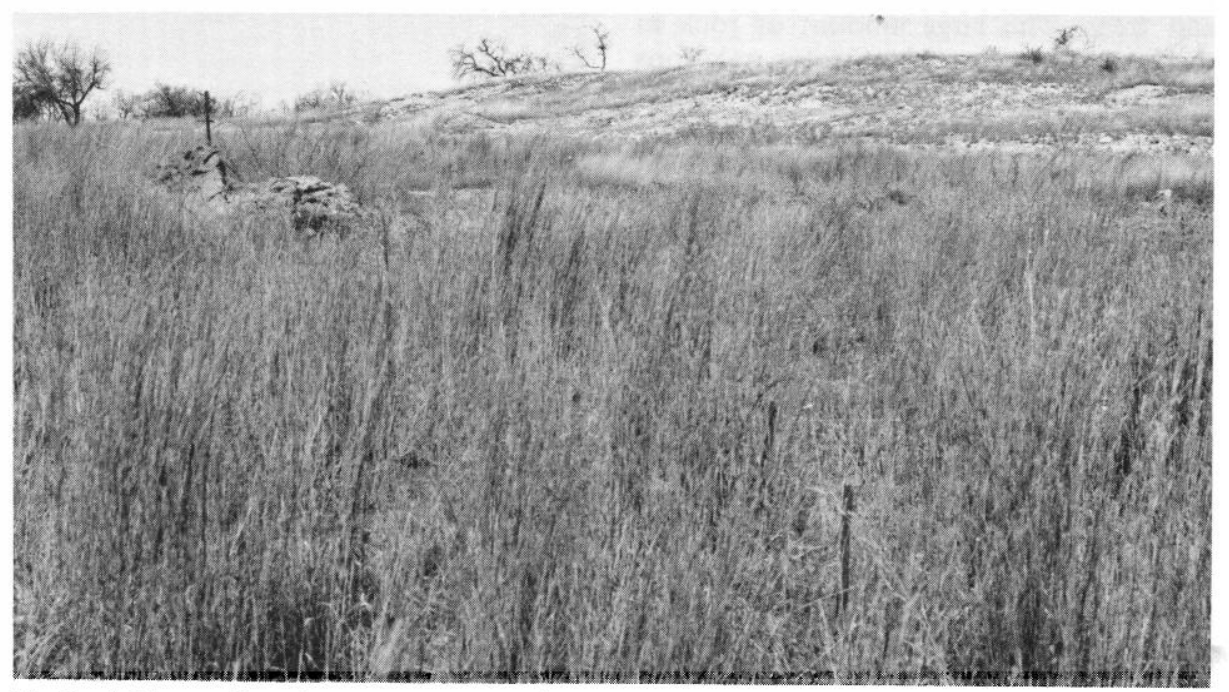

Fig. 3. With excellent late summer rains following the spring drouth, little bluestem was completely recovered by October 21, 1971 (same photo point as Fig. 2d, e, and f). after a drouth following a burn, plants seem to recover very rapidly. In October following $40 \mathrm{~cm}$ of summer precipitation on the 1971 burn, little bluestem had fully recovered and tall grama was near full recovery (Fig. 3) as shown in the following tabulation: Little bluestem (burned) $6527 \mathrm{~kg} / \mathrm{ha}$; (unburned) 5448 . Tall grama (burned) $2043 \mathrm{~kg} / \mathrm{ha}$; (unburned) 2486. The other three species remained unchanged from the July clipping.

Vegetation on the burned juniper pile areas was very different from the surrounding vegetation (Fig. 4), since the piles burned much more intensely than fine fuels. Silver leaf nightshade (Solanum elaeagnifolium) and Carolina horsenettle (Solanum carolinense) were dominant plant species on the burned pile areas; vegetative cover was $9.1 \%$ compared with $37.0 \%$ on the surrounding areas. Smooth leaf sumac (Rhus glabra) also became more prominent on burned areas and very hot fires.

\section{Pile Consumption and Tree Mortality}

The fire did not carry through two plots, which had 768 and $952 \mathrm{~kg} / \mathrm{ha}$ of fine fuel. Where fine fuels were above seemed to thrive after burning, even after 


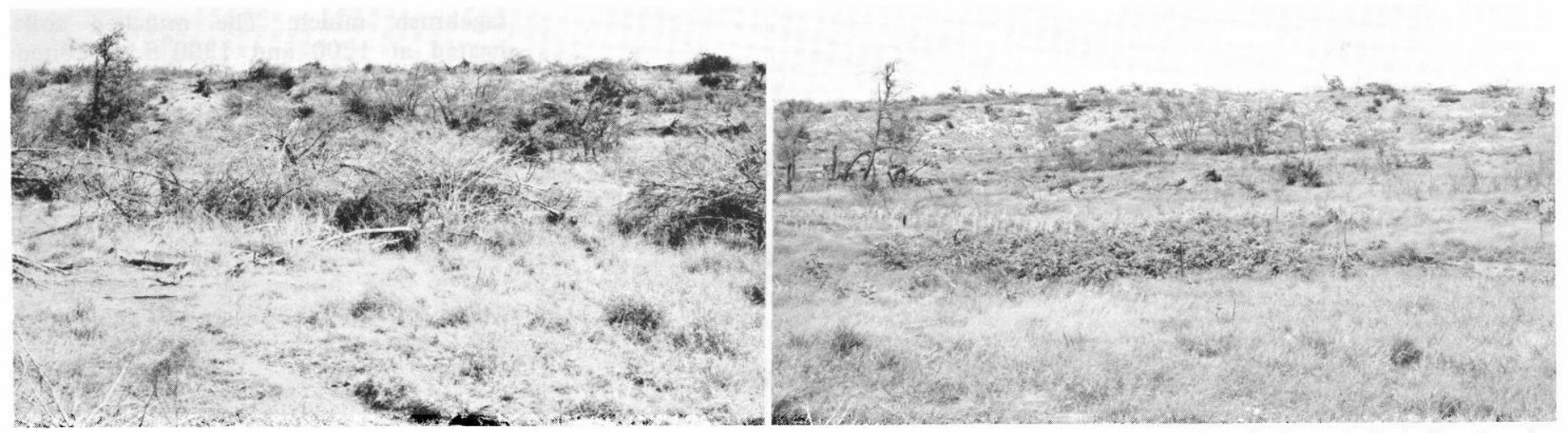

Fig. 4. Juniper piles burn much more intensely than grass areas and are occupied by weeds for the first few years after the burn. Left-before burning. Right-weeds established on burned area.

$1,000 \mathrm{~kg} / \mathrm{ha}, 99 \%$ of the piles were consumed by fire. This is a higher consumption than that reported by Arnold et al. (1964) on juniper slash; however, the fire in our study followed 6 months of very dry weather and was conducted under the lowest humidities and highest winds that could be tolerated for prescribed burning.

The arrangement of fine fuel is also important in determining its effectiveness to carry a fire. A $1,037 \mathrm{~kg} /$ ha plot carried a good fire over a continuous turf of buffalograss and Texas grama (Bouteloua rigidiseta). A $952 \mathrm{~kg}$ /ha plot that did not carry a fire had widely spaced bunches of tall grama. Thus, the minimum amount of fuel necessary to carry fire in sod grasses is probably less than for bunchgrasses. Cable (1967) and Dwyer and Pieper (1967) reported less fuel to carry fire than was reported in our study.

Where large juniper piles were within $12 \mathrm{~m}$ of each other, firebrands would ignite the piles downwind, and fine fuel was not necessary to carry the fire. In general, this is not a safe way to burn high concentrations of juniper piles because they may behave as one large pile and project live firebrands over $300 \mathrm{~m}$.

Mortality of ashe juniper was high where adequate fine fuel was present to carry the headfire $(1,000 \mathrm{~kg} / \mathrm{ha})$. In the areas that burned, only one of 368 marked trees remained alive. Trees over $1.8 \mathrm{~m}$ tall were not marked, but it was observed that many of them were killed by the fire. When the amount of fine fuel was $2,240 \mathrm{~kg} / \mathrm{ha}$ or greater, there was a good kill on all trees present. Dwyer and Pieper (1967) and Dalrymple (1969) found tree mortality to decrease as tree size increased. However, both studies followed fires with less than $1,000 \mathrm{lb} / \mathrm{acre}$ $(1,120 \mathrm{~kg} / \mathrm{ha})$ of fine fuel.

\section{Summary and Conclusions}

Ashe juniper communities were burned in the spring of 1970 and 1971 near Baird, Texas, to determine the effect of fire on yields of five dominant grass species and the amount of fine fuel necessary for a fire to consume piles and kill young juniper trees. Winter and spring were very wet in 1970 but very dry in 1971.

Burning increased the yields of little bluestem and meadow dropseed after the wet winter and spring of 1970 . Yields of sideoats grama, vine-mesquite, and tall grama remained unchanged. Numerous vine-mesquite stolons grew into unoccupied areas. In 1971, after a dry winter and spring, yields of little bluestem, sideoats grama, and tall grama decreased about 50\% after burning. Vine-mesquite and meadow dropseed increased on bottomland sites.

During a dry spring where the amount of fine fuel was $1,000 \mathrm{~kg} / \mathrm{ha}, 99 \%$ of the piles were consumed and $99 \%$ of the juniper trees less than $1.8 \mathrm{~m}$ tall were killed by headfires.

Soil moisture should be a primary consideration before conducting a prescribed burn. With good soil moisture, plants can begin to grow immediately after the burn; recovery is rapid and soil erosion is minimal. Without good soil moisture, which is usually the case when wildfires are common, burning increases the drouth stress on plants and herbaceous yields are reduced. The soil may also remain bare for several months and be subjected to severe wind and water erosion.

\section{Literature Cited}

Aldous, A. E. 1934. Effect of burning on Kansas bluestem pasture. Kans. Agr. Exp. Sta. Tech. Bull. 38. p. 65.

Arend, J. L. 1950. Influence of fire and soil on distribution of eastern red cedar in the Ozarks. J. Forest. 48:120-130.

Arnold, J. F., D. A. Jameson, and E. H. Reid. 1964. The pinyon-juniper type of Arizona: Effect of grazing, fire, and tree control. U. S. Dep. Agr. Production Res. Rep. No. 84. p. 21-24.

Aro, R. S. 1971. Evaluation of pinyon-juniper conversion to grassland. J. Range Manage. 24:188-197.

Box, T. W., J. Powell, and D. L. Drawe. 1967. Influence of fire on south Texas chaparral communities. Ecology 48:955-961.

Burns, P. Y. 1952. Effects of fires on forest soils in the pine barren region of New Jersey. Yale Univ., School of Forestry, Bull. $57.50 \mathrm{p}$.

Dalrymple, R. L. 1969. Prescribed grass burning for ashe juniper control. Progress Report from Noble Foundation, Inc., Ardmore, Oklahoma, 73401.

Dix, R. L., and J. E. Butler. 1954. The effects of fire on a dry, thin soil prairie in Wisconsin. J. Range Manage. 7:265-268.

Dwyer, D., and R. D. Pieper. 1967. Fire effects of blue grama-pinyon-juniper rangeland in New Mexico. J. Range Manage. 20:359-362.

Emerson, F. W. 1932. The tension zone between the grama grass and pinyon-juniper associations in northeastern New Mexico. Ecology 13:347-358.

Fowells, H. A., and R. E. Stephenson. 1934. Effect of burning on forest soils. Soil. Sci. 38:175-181.

Jameson, D. A. 1961. Growth inhibitors in native plants of northern Arizona. U. S. Forest Serv., Rocky Mountain Forest and Range Exp. Sta. Res. Note 61. 2 p.

Johnsen, T. N. 1962. One-seeded juniper invasion of northern Arizona grassland. Ecol. Monogr. 32:187-207.

Kucera, C. L., and H. H. Ehrenreich. 1962. Some effects of annual burning on central Missouri Prairie. Ecology 43:334-207.

Lavin, F., D. A. Jameson, and F. B. Gomm. 1968. Juniper extract and deficient aeration effects on germination of six range species. J. Range Manage. 21:262-263.

McMurphy, W. E., and K. L. Anderson. 1965. Burning Flint Hills range. J. Range Manage. 18:265-296.

Old, S. M. 1969. Microclimate, fire, and plants production in an Illinois prairie. Ecol. Monogr. 39(4):355-384.

U. S. Forest Service. 1963. Annual Report. U. S. Dep. Agr., Rocky Mountain Forest and Range Exp. Sta. 77 p.

Wells, P. F. 1970. Post glacial vegetational history of the great plains. Science. 167:1574-1582.

Wright, H. A., C. M. Britton, R. L. Wink, and B. Beckham. 1972. A progress report on techniques to broadcast burn dozed juniper. Tall Timbers Fire Ecol. Conf. Proc. 12:169-174. 